\title{
In place of 'global democracy'
}

\author{
Michael Saward, \\ The Open University
}

\begin{abstract}
In the present contribution, I discuss something that is not 'global democracy'. Global democracy is too facile a name for something, the shape of which (as if it could have a single shape) remains unknowable. I begin by sketching key reasons for caution about invocations of 'global democracy'. Laslett was right to say we need to think more about political forms - where do transnational forms come from, how do they crystallise and become formalised? Are new procedures 'designed', or do they emerge from what a range of institutions and actors do and create? I move on to look at the unavoidable particularity of invocations of global democracy, in terms of varying narratives and emphases. I then sketch an alternative, reflexive and focused way to think about democratic practices in transnational spaces.
\end{abstract}

KEYWORDS. Global democracy; political theory; representation; transnational; reflexive

'A single world government ... sustained by the familiar apparatus - universal voting, federal provisions, party allegiance and competition - is the picture that seems to come to mind when people reflect on remedying the universal environmental crisis, [but] the model itself seems a little conventional. Surely the fresh intellectual borizons which are opening out should persuade us to think again about political forms as well as political assumptions' (Laslett 2003).

$\mathrm{T}$ here is no doubt that the issues that provoke discussion of global democracy are pressing ones. Transnational issues around global warming, HIV/AIDS, biodiversity, poverty or war are, or may become, fateful in quite literal terms as well as in the sense of being unavoidable (though unevenly so). Of course, these 'issues' are themselves mediated, framed and represented to different audiences in particular ways - there is no unmediated access either to their content or the action they demand. 
The institutional choices that powerful international organisations and actors make in confronting these issues are critical, and some such choices will ultimately affect us all - we are all fated to be implicated in global dilemmas to some degree (there are no full opt outs, or left outs).

\section{REASONS FOR CAUTION: NAMING 'GLOBAL DEMOCRACY'}

The core of this article is built on scepticism about the notion of global democracy. The fact that the notion is problematic, however, does not reduce its seductive power.

First among the reasons for its being problematic is the sheer number and range of actors and practices, with their complex linkages and conceptions, operating in transnational spaces. To talk of global democracy may reflect a conscious or unconscious desire to simplify the complexity, but that in itself is not a point in favour of so doing.

One notable factor of this complexity is the fact that we cannot predict which 'control mechanisms' that are 'nascent' in transnational spaces will come to be 'institutionalised' (Rosenau 2000). There are multiple emergent political mechanisms, with multiple intended and unintended functions, in and across transnational spaces. These mechanisms may be political in different senses: decisional, regulatory, monitory, and so forth. Often enough, they will emerge due to their perceived efficacy in dealing with some immediate sectoral pressures or issues. Great retrospective selectivity is required of anyone looking to pinpoint 'designs' for 'global democracy' out of this open-ended, uneven and changeable set.

Despite these points, the very process of invoking 'global democracy' grants it an air of 'thingness' that can make it seem real, or realisable. Even persistent claims of its absence give it a presence of sorts, in the sense of it being a unitary and accepted object of various academic and political debates. Desirability is a key factor behind invocations. ${ }^{1}$ Invoking global democracy trades strongly on the idea that (much) more 
democracy is attainable than we currently have (see, for example, Held 1995; Young 2000). The notion conveys its own rhetorical approval. ${ }^{2}$ The symbolism helps: a globe is traditionally a symbol expressing completeness, perfection, and powerful wholeness (de Vries 1984). There are clear attractions of the novel and the innovative; 'global democracy' conveys a startling sense of newness. There is the attraction of working through the paradox that arises (global democracy?). And of course there are the attractions, tempting to political theorists, of adopting the stance of the system-builder, positioning oneself as someone with the authority to design. For these sorts of reasons, democratic theorists and others are certainly not above offering prescriptive grand designs for global democracy. ${ }^{3}$ The real awkwardness in this self-positioning is captured by Gunnell:

The paradox of normative political theory is simply that the 'knowledge' it professes is not knowledge about anything unless that knowledge is practically manifested or acknowledged ... The academic voice is as legitimate and credible as many others in the political arena ... however ... the politics about which many do speak is often a philosophical construction and ... in many instances scholarship has been replaced by pronouncements grounded in claims to various forms of epistemic privilege which do not fit comfortably with the typical expressions of democratic sentiment (Gunnell 2006, 781). ${ }^{4}$

So, neither the possibility nor the desirability of 'global democracy' should be taken on board uncritically. Let's take a specific example. According to Craig (2008), drawing on writers such as Wendt (2003), the idea of world government is 'resurgent'. Collective action problems mean that some countries will 'free ride' when it comes to addressing (for example) global warming or humanitarian intervention. A number of world government advocates argue that the latter is the 'only entity that can solve' such problems (Craig 2008, 2). Such analyses gloss over some real difficulties. 'Free riding' may have very different meanings in different cultural and political contexts. Different countries and cultures will have highly varied 
inclinations to rate and rank 'global issues' in different ways - and likewise differential capacity and willingness to consider or confront them. Despite the apparent need, a 'world government' would face enormous difficulties in producing agreed solutions (consider solutions to 'the threat of terrorism', for example). And even if it could produce solutions, how could it gain sufficient authority to implement them? (How could it stage its claim to the ultimate monopoly of legitimate force?) Would its authority be rooted in a gamble on the permanence of the 'problems' to be dealt with, in which case we might be talking about world government's incentive not to solve problems, or at least to perpetuate solution-gathering processes? In short, there is a vulnerability to a number of major assumptions underlying the world government case.

I want to defend briefly my use of 'transnational spaces' to describe the arenas - geographical or functional - in which specific political innovations and practices occur. To talk of 'global space' carries a strong sense of commonality of treatment, experience, need, or concern for all parts of the globe that is unlikely to be justified in most specific cases. Even discussions of 'global warming', for example, quickly break down into which parts of the world are most vulnerable to it, responsible for it, or responsible for alleviating it. In addition, questions of differential development, poverty, and wider economic and social responsibilities then enter the debates. In short, 'global space' is a term that is vulnerable to being far too general to help express the character, impact, and challenges of global warming. 'International space' as an expression carries similar problems - implying as it does that at some level all states are implicated in the issues at hand in some more or less common way. Referring to 'transnational spaces' is preferable; 'transnational' refers not to global or even international, but is a more flexible notion that can express 'across nations', whatever the number implicated in a specific issue. It carries no connotation of commonality of impact or treatment. 'Spaces' likewise allows for a greater sense of the plurality with which spaces are constituted and affected by transnational activities, for example the shifting 
invocations of space that accompany renderings of transnational environmental, security, military, and financial issues.

\section{NARRATIVE THREADS AND EMPHASES}

In this section, I want to reinforce the unavoidable particularity, and therefore the radical plurality, of invocations of global democracy. Narrative threads that offer different accounts of what is occurring in transnational politics link together (variously) objects of concern, issues, actors, concepts and models. In addition, different emphases regarding what aspects matter most are evident, for example policies, patterns of interaction, and space. These pose a challenging set of problems for 'democracy', a theme I will return to in the next section of the article.

When it comes to 'global democracy', what is the object of concern, or initial motivation? Some are led to concerns about transnational politics and governance by specific issues, such as major environmental issues (Eckersley 2004). Others are led for example by a concern for a lack of financial regulation. Others still are motivated by the perceived possibility of transcending national democracy (Falk 2007).

Factors that lead participants or observers to a particular concern about transnational politics, lead them in turn to focus on certain actors. There are actors implicated or named within those domains of concern - for example INGOs, TNCs, governmental and umbrella institutions like the UN, the World Bank, the IMF, and the EU and their satellites and affiliates. The study of some areas of concern tends to lead to the study of certain actors more than others - those concerned with a lack of economic regulation will often focus on TNCs for example.

Going a step further, the examination of particular sets of concerns and actors tends to generate distinctive sets of concepts. Transnational politics has surely been one of the most fruitful domains for phrase-making in political science in recent years. Transnational advocacy networks 
(TANs) are discussed especially by those focused on pressing issues featuring non-governmental actors (e.g. Keck 2004). 'Governance regimes' tends to be a wider concept bringing together 'governmental' and 'nongovernmental' actors around certain issues or problems. Various concepts of networks, such as 'network governance', have a similar provenance (cf. Dryzek 2000; Keck 2004). Corporate social responsibility (CSR) and corporate citizenship arise from management and business studies literatures. There are many more - polylateralism, cosmocracy, complex sovereignty, and so on (see Scholte 2007). Such concepts are intended to capture the nature of the connections and interactions between actors around issues (or in issue areas).

While not all narrative threads have resulted in the production of models of democracy, conceptions of democracy advocated will be generated from the focus of one's specific concern, and the consequent types of actors and concepts considered. So, for example, if one's concern is with the unregulated behaviour of key actors in the global economy, the focus is likely to fall on transnational corporations (TNCs), and the idea of democracy to be inflected through ideas of corporate citizenship, corporate social responsibility, or modes of corporate engagement with stakeholders (Thompson 2005). If the concern is with transnational governance (its incoherence, perhaps, or its lack of popular accountability), then designing cosmopolitan models of democracy will be a key focus (Held 1995; Young 2000). If one sees 'global civil society' as a prime and necessary democratising force in transnational politics and economics, then international non-governmental organisations (INGOs), and perhaps the transnational actor networks (TANs) through which they sometimes operate may lead to conceptions of democracy that favour open and discursive views of democratisation (e.g. Keck 2004; Dryzek 2000; Galtung 2000; Falk 2007).

Different narrative threads also tend to emphasise different aspects of what is most significant about studying transnational political activity within a given thread. For example, one might emphasise policy areas, as do some whose primary starting point is 'environmental politics', or 'the 
politics of security'. Alternatively, one might emphasise innovative or emergent patterns of interaction (such as governance regimes or networks). Some might stress formal governmental processes, as in intergovernmental or other institutions like the UN, while others might focus on the novel nature of the space(s) invoked by these patterns or processes, for example 'global civil society'. Finally, one might draw attention to the novel style of political activity, for example 'discursive representation', which has been identified as modifying our conventional understandings of representation (Keck 2004; Dryzek 2000). In short, what can look like one debate is in fact a series of sometimes separate, sometimes overlapping debates.

Different narratives carry different emphases, depending on what they feel is most novel or academically 'newsworthy', as well as different content in terms of issues, actors and concepts.

\section{The CHALLENGE TO 'DEMOCRACY'}

These general comments are intended to stress the empirical and conceptual complexity that invocations of 'global democracy' invite. They help to put in place a sense of the real constraints on how 'democracy' might be addressed with respect to politics in and of transnational spaces. To leap blithely over these layers of complexity to advocate over-simple models of 'global democracy' is to be utopian in the negative sense offering designs or solutions that apply to 'no place'. If this is the level of complexity we are dealing with when it comes to issues, institutions, processes, patterns, actors and styles of politics in transnational spaces, invocations of democracy need to take it on board. Transnational space is of variable depth and content; some parts of it are in a dynamic process of 'semi-constitutionalisation' (Thompson 2005) or 'rule-making' (Cohen and Sabel 2006) by a variety of actors and institutions. Many others are not. Rule-making institutions are multi-level, private as well as public, informal and semi-formal as well as formal (Bellamy and Jones 2000). 
'Democracy' can be - and has been - invoked at various points in the changeable and complex matrix of politics in transnational spaces. In an effort to distil the message of the discussion so far, however, we can say that there is little basis on which to discuss democracy in transnational spaces without fully taking on board:

1. Fuzzy functionality: there is no settled or prescribed unit for democracy in transnational spaces, no geographical or functional gap or vacuum of a clear or persistent size to be filled, so any invocation of democracy needs to cope with its inevitably partial and unsettled nature.

2. Disjointedness: democratic blueprints aim at internal connectedness as well as completeness, but the nodes of connection in transnational spaces do not allow for this.

3. Arbitrary entry points: invocations of democracy in this context ride on the back of specific concerns (about issues, problems, actors, processes, etc.).

4. Pragmatism: designs are situated designs, even if they show promise of later pragmatic transfer or adaption in geographical or functional terms.

5. Practical enactment: whatever the theorists say or do, practitioners and activists will do the bulk of the designing (whether they know they are doing it or not).

6. The known unknown: if 'global democracy' has a telos, we do not know what it is.

These points clearly have significant implications for what it might mean to invoke democracy in transnational spaces. I will explore briefly a couple of these in the remainder of the article.

\section{A REFLEXIVE APPROACH TO ENACTING DEMOCRACY}

What the above points amount to, when it comes to invocations of democracy, is that we need to be: (a) reflexive, in the sense of moving from specific theories or concepts to contextual practices and back again; and (b) modest 
in terms of the temporal, spatial or functional reach of any given invocation. To embrace limits is also to embrace opportunities; setting aside unrealistic blueprinting opens up other possibilities. Below, I briefly sketch and illustrate what taking a reflexive and contextual approach to democracy in transnational spaces might involve, and how such an approach may impact upon invocations of selected democratic principles.

While it might seem that the above summary (see points 1-6) leaves little space for thinking about democratic institutions, I will now briefly discuss an approach that sets aside macro models for reflexive micro modelling. ${ }^{5}$ My stance here is modest, micro-level, and makes no claims about present or emergent properties of something called global democracy. It stresses the importance of exploring particular real-world democratic innovations, and having an openness to novel practices of democracy. A key concern is the tailoring, adaption and devising of democratic procedures for specific new challenges and (given the nation-state-based way that we are used to thinking about democracy) unfamiliar political contexts. This stance will enable us to pick up on a number of principles and mechanisms linked to democracy that have been discussed as operating, in some form, in transnational spaces.

A common approach to democratic theory designs is a deductive one - starting with core abstract principles, normally equality, and deducing other principles along with specific institutions that are intended to realise the principle(s) in practice. This is broadly the approach that Dahl (1989) for example takes to national level democracy, and the one that Held (1995) takes for 'cosmopolitan democracy'. The alternative approach I suggest here is one in which principles associated with democracy - equality, freedom, participation, accountability, and so on - get their meaning from practices and institutions that enact them. I use the term 'devices' for these practices and institutions. Principles like equality can and do mean different things in different contexts; different mechanisms will also enact them differently. Indeed, we can say that principles are primarily things that are done, rather than rights or statuses that are conferred. ${ }^{6}$ Principles are 'done', and get their meaning, from being enacted in specific devices 
in specific contexts. This starting point takes us away from the notion that grand, deductive designs are feasible - or, specifically, that they will be of much practical use

There is a wide range of democratic and potentially democratic devices that can enact desired principles; democracy can mean, and can look like, many things, and we should be open to unfamiliar but acceptably democratic constructions. Democracy, after all, is always democracy-to-come, in Derrida's terms.

A device is a mechanism that plays a part in constituting a more-orless formal procedure by which binding collective decisions are reached for a political community. At a given time, certain devices for enacting democratic principles are familiar, others are not. Some may be in the very early stages of practical experimentation. What sorts of sample devices can we say are available today? What follows is an indicative set of reasonably familiar nation-state based devices:

- systems of representation

- an elected parliament with legislative authority

- implementational (and other) public agencies

- elections for representatives, and voting

- majority rule as the key to interpreting elections and other votes

- proportionality as an alternative aggregative device for interpreting elections and other votes

- the citizens' initiative

- the referendum

- public hearings, debates, and inquiries

- protected 'public spaces' of civil freedom

- delay or pause

- judicial review through independent courts overseeing due process

A sample of newly emergent devices that might with some plausibility take on a democratic character (nationally or transnationally), or be deployed with convincing democratic purpose, might be: 
- virtual assemblies

- deliberative opinion polls and citizens' juries

- televoting on issues

- electronic town meetings

- transnational citizenship

- functional citizenship

- private voting and pressure voting

- reciprocal representation

- cross-border referendums

- policy-initiating social forums

- policy-initiating stakeholder forums

- participatory budgeting

- functional subsidiarity

- autonomous associative governance

- authoritative private regulation of delimited public goods

Clearly a great deal more can and should be said in detail about levels and types of devices. My present aim, however, is to sketch a broad picture of devices and their potentialities - especially variations and new combinations of practices that are subject to specific, current experimentation.

Which devices may be useful, and how (and how long), in a given issue-context is always bound to be contestable. Consider, for example, the extraordinarily high incidence of HIV/AIDS infection in a number of countries in sub-Saharan Africa. ${ }^{7}$ There have been varied suggestions that HIV/AIDS has had a deleterious impact upon democracy, but that it has also begun to show how democratic adaptiveness may help in dealing with aspects of a phenomenon that is causing enormous suffering. Innovative, contextual political responses to some extent have, and further might, include the following devices or initiatives. The empowerment of women through combinations of entrenchment and enforcement of women's rights may highlight the burden of care roles and discrimination against women. Forms of functional decentralisation of authority to 
communities, with central government and NGO support, may assist in placing solutions at local levels in local hands. Creative use of a crossnational equivalent to a deliberative opinion poll, drawing together a representative sample of citizens from a number of countries and giving them access to medical, political, logistical and other specialist experts, may play useful empowerment, pressuring and informational roles. Forms of reciprocal representation among parliaments and local authorities of affected countries may reinforce a sense of common purpose. Parliaments might innovate through creative ring-fencing of social resources. Formalised styles of stakeholder participation may bring together government, corporate (e.g. drug companies) and non-governmental organisations in policy-making and delivery concert. International and national monitory bodies can be empowered in specific ways to co-ordinate with delegations from national governments to oversee policy programmes and their implementation. This, of course, is not an adequate account of a huge and complex issue. I aim only at a very brief and illustrative discussion of what it might mean to rethink democracy reflexively in transnational spaces.

Democracy exists through its enactment, and its potential modes of enactment are more open than we commonly think. The capacity for developing, deploying and creatively sequencing both familiar and novel devices at different levels, confronted by specific tasks or challenges, make the enactment approach especially suited to thinking about politics in transnational spaces. 'Global democracy' may be beyond present reach we don't know (have not yet conceived) what the relevant devices may be, therefore cannot anticipate combinations and sequences and incentive effects. Nevertheless, we can anticipate that democracy's reflexivity may produce invention, adoption and transfer of sequenced devices for novel transnational problems or purposes, and that democracy will be done differently - with emphasis on different principles, enacted through distinctive combinations of devices - at different times and in different transnational spaces. 
V. THE LIFE OF DEMOCRATIC PRINCIPLES IN TRANSNATIONAL SPACE REFLEXIVITY AT WORK

Thinking about democratic principles reflexively means to link them to contexts, to see them as gaining meaning from specific enactments rather than from abstract definitions. Reflexivity is essential if we are to take on board fully the challenges and analyses distilled into points 1-6 above.

In the sections that follow, I shall briefly illustrate some of the challenges that selected democracy-linked principles have already faced in analysis and practices of transnational politics, noting some adaptations and innovations in democratic devices. The point is that multiple adaptions are already happening (tip of the iceberg though they may be), and that through a number of such specific instances our ideas of democracy may be undergoing significant mutation and modification. This is not a 'model' or a blueprint, however, it is capturing some specific, pragmatic adaptations that may begin to capture in turn partial trajectories of democracy in transnational spaces.

\section{Accountability}

The standard description of democratic accountability holds that key officials are held to account via elections involving geographically-defined constituencies at national or sub-national levels (with the notable exception of the European Parliament on the latter point). The sporadic and complex nature of politics in transnational spaces, however, does not have the key components of this familiar conception to fall back on. Fixed or settled senses of who votes from what constituency and for whom are lacking (though something along these lines is more familiar from proportional representation systems). Other possible modes of accountability thus enter the picture, controversially because their novelty places them outside conventionally acceptable bounds of the principle's previous applications. Let me illustrate by mentioning four such possibilities. First, 
accountability might not be to a territorial constituency, but rather to a body that monitors transnational processes and actors. ${ }^{8}$ The monitor, in a sense, stands in the place of an electoral constituency in a more openended conception of the 'public interest'. UN agencies that monitor national and regional progress on environmental goals or the millennium goals might be one prominent example in this regard. Of course, this raises further questions concerning the accountability of the monitors. Accountable to whom?

Second, accountability might be conceived in terms of outcomes (or outputs) rather than processes. This is partly because, in a number of transnational spaces, direct or formal relations of accountability to those who are involved in decision-making processes may be lacking. Third, accountability might be conceived less in terms of formal, e.g. electoral, answerability than in the 'giving of accounts', of explaining oneself to those who may be affected by decisions or procedures in which one is involved. INGOs or transnational corporations, for example, might be seen in this light. Publicity arguably becomes a more significant component of accountability's operation in this sort of context. Finally, one could think in terms of 'complex accountability', where multiple modes of accountability of powerful actors and organisations may compensate for the imperfections of single lines of accountability in the absence of the more familiar nation-based mechanisms. A mix of forms of control, such as statutory objectives, budgetary discipline, professional monitoring and interest group monitoring, could make up such a system of complex accountability (Majone 1995).

\section{Citizenship}

Ideas of citizenship are being partially recast in some processes, and by some actors, in transnational spaces. Citizenship at the national level has been, and remains, primarily about legal or formal status. In transnational spaces the picture varies, but at a general level there is no equivalent status. 
Statuses that matter tend towards different forms of recognition, which are geared for far more specific purposes than the status of national citizenship. The idea of citizenship as action (or acts) rather than as status, however, comes more into focus in transnational spaces. There can be little doubt that 'citizenship' is a word that commends the one it attaches to, and so it should not be surprising that there is a rhetoric of claims to citizenly character at any level. Transnational corporations in particular, however, have become keen to portray themselves as 'good corporate citizens', often through 'corporate responsibility' programmes. Nongovernmental organisations operating in transnational spaces sometimes see themselves as citizens, or substitutes for citizens, in their publicminded actions. If it turns out that this is a plausible perspective from points of view other than the claimants', notions of 'transnational civil society' may begin to take on substance. More broadly, the ideas of the 'global citizen' and 'citizen of the world' have become more prominent in recent years, reflecting the act rather than status based idea of citizenship as well as challenging the nation-state as a horizon of moral concern.

Clearly, such ideas take the familiar into unfamiliar domains. Accountability's meaning is stretched, shrunk, distorted, and contorted. Some innovative invocations will fade; others may gain traction among theorists and practitioners.

\section{Representation}

A particularly rich set of practices and claims about, and by, actors in transnational space have introduced pockets of new thinking about the principle and mechanisms of representation. There is no supra-national territorial basis on which to replicate the nation-state basis of representation (with the specific and partial exception of the European Union). So, just who is to be represented, who or what can do the representing, and how this representing might be done is an area of innovation in transnational spaces. 
The idea of 'stakeholder' representation has gained prominence in areas of transnational politics. One especially prominent example has been the set of policy networks and processes associated with the UN Commission for Sustainable Development (CSD). The CSD, along with other UN agencies, has formally recognised partnerships with civil society organisations and encouraged certain forms of participation by NGOs in its processes for some years. A prominent instance of this was the 2002 World Summit on Sustainable Development (WSSD) in Johannesburg. Representatives of nine Major Groups (including business, labour, farmers, women, and indigenous peoples) took part in key summit events as formal participants. There were varying degrees of 'chosenness' of these representatives, and varying degrees of accountability back to a base of their 'group'. Nonetheless, it was a way of summoning up demoi and a selection of spokespersons for those demoi.

Stakeholding, of course, raises many other questions. Just who is (or counts as) a stakeholder, for example? Is it someone (or a group) who is affected by a possible decision or policy? Or someone whose support is needed to make the decision work? Perhaps it is any group or person who is vulnerable, or who stands to lose, as the result of a decision (a more 'protective' variation of affectedness)? Perhaps is it whoever claims a stake, or then again whoever has the skills and expertise to make the decision a good one or the right one? Arguably, stakeholder governance in and around the WSSD contained elements of each of these definitions. Further, such cases of stakeholder representation will always raise questions about representativeness. To what extent, for example, is an appropriately wide range of stakeholder groups participating formally? To what extent are participating representatives chosen by, or otherwise accountable to, a wide range of grassroots members of the communities or collectivities they are drawn from and speak for? Finally, to what extent is there flexibility in including stakeholder groups whose participation is germane to the problem at hand?

Other key issues thrown up by practices of representation in transnational spaces include redesignations of the term following novel practices. 
Keck (2004), for example, writes of 'discursive representation' where there is no electoral link between would-be representeds and representatives in some transnational politics, but where the purported interests of some group is articulated by another. Varied modes of non-electoral representation are being explored - potentially democratic despite lacking an electoral grounding (Saward 2009). Interestingly - in a demonstration of the different ways that specific and novel transnational practices can be construed - Galtung refers to a very similar process as being one of 'articulation' instead of representation (Galtung 2000). Dryzek and Niemeyer (2008) refer to a different set of phenomena under the heading of 'discursive democracy' - the representation of 'discourses' rather than (or prior to) persons.

In short, the richness of possible spaces and modes of political representation in transnational spaces (which include, of course, national and local spaces) opens up experimentation and argument that evokes 'democracy', whether as a friend or an opponent. Once again, these are very early days for transnational politics and there is no clearly discernible trajectory.

\section{Concluding COMMent}

Clearly there is much more to be said on this topic - what it might mean to sequence devices (old and new) in ways that might exploit myriad political openings in transnational spaces. Elsewhere, I have outlined the attractions of devices and variants such as reciprocal representation and cross-border referendums, for example, along with the benefits of thinking of governance mechanisms as temporary as well as permanent and as non-governmental as much as governmental (Saward 2000). We have also considered varied democratic benefits and challenges associated with institutionalising stakeholder participation in global summits (Backstrand and Saward 2004).

My purpose here has been to clarify the reasons for thinking of democratic designs in a micro-level and reflexive manner that is far distant 
from ready invocations of 'global democracy'. Such an approach can help us to combine creativity and novelty with feasibility, and immediacy and impact with due modesty. As Laslett suggests, there is much thinking to be done about both political forms and political assumptions.

\section{WORKS CITED}

ABC Radio National, Background Briefing (2001), "George Monbiot: global democracy." Available from http://www.abc.net.au/rn/talks/bbing/stories/s416171.htm. Internet, accessed 13 August 2008.

Bäckstrand, Karin and Michael Saward. 2004. Democratizing global environmental governance? Stakeholder democracy at the World Summit for Sustainable Development. Paper presented at the Annual Meeting of the American Political Science Association, September 2-5 2004, in Chicago.

Bellamy, Richard and R. J. Barry Jones. 2000. "Globalization and democracy - an afterword.” In Global Democracy: key debates, 202-216. Ed. Barry Holden. London: Routledge.

Butler, Judith. 1980. Gender Trouble. New York: Routledge.

Cohen, Joshua and Sabel, Charles F. 2006. "Global democracy?" International Law and Politics 37: 763.

Craig, Campbell. 2008. "The resurgent idea of world government," Ethics and International Affairs 22: 2

Dahl, Robert A. 1989. Democracy and its Critics. New Haven: Yale University Press.

De Vries, Ad. 1984. Dictionary of Symbols and Imagery. Amsterdam and London: Elsevier Science Publishers.

De Waal, Alex. 2008. "AIDS in Africa: coping with crisis." The Journal 5.

Dryzek, John S. 2000. Deliberative Democracy and Beyond. Oxford: Oxford University Press.

Dryzek, John and Simon Niemeyer. 2008. "Discursive representation." American Political Science Review 102: 481-493.

Eckersley, Robyn E. 2004. The Green State. Cambridge, MA: MIT Press.

Falk, Richard. 2007. "What comes after Westphalia: the democratic challenge." Widener Law Review 13, 2.

Galtung, Johan. 2000. "Alternatives models for global democracy”, in Global Democracy: key debates, 143-161. Ed. Barry Holden. London: Routledge.

Goodin, Robert E. 2008. Global democracy: in the beginning. Paper presented at the Annual Meeting of the American Political Science Association, 28 August in Boston.

Gunnell, John G. 2006. "Dislocated rhetoric: the anomaly of political theory." The Journal of Politics 68, 4.

Held, David. 1995. Democracy and the Global Order. Cambridge: Polity. 
Keane, John. 2008. Monitory democracy. Paper presented at the workshop on The Future of Representative Democracy, Gulbenkian Foundation, 13-15 December, Lisbon.

Keck, Margaret E. 2004. "Governance Regimes and the Politics of Discursive Representation." In Transnational Activism in Asia: Problems of Power and Democracy, 43-60. Ed. N. Piper and A. Uhlin. London: Routledge.

Laslett, Peter. 2003. "Environmental ethics and the obsolescence of existing political institutions." In Debating Deliberative Democracy. Ed. James S. Fishkin and Peter Laslett. Oxford: Blackwell.

Majone, Giandomenico. 1995. "Independence Versus Accountability? Non-Majoritarian Institutions and Democratic Governance in Europe." In The European Yearbook of Comparative Government and Public Administration (vol.1, 1994), 117-140. Ed. Joachim J. Hesse and Theo A.J. Toonen. Baden-Baden: Nomos Verlagsgesellschaft and Boulder, CO: Westview Press.

Manning, Ryann. 2002. AIDS and democracy: what do we know? Paper presented to a University of Natal Health Economics and AIDS Research Unit (HEARD), University of Cape Town Democracy in Africa Research Unit, and Institute for Democracy Governance and AIDS Programme Workshop on 'Democracy and AIDS in Southern Africa: Setting the Research Agenda', April 22-23 in Cape Town, South Africa.

Rosenau, James N. 2000. "Governance in a globalizing world." In The Global Transformations Reader, 223-233. Ed. David Held and Anthony McGrew. Cambridge: Polity.

Saward, Michael. 2000. "A critique of Held." In Global Democracy: key debates, 32-46, Ed. Barry Holden. London: Routledge.

Saward, Michael. 2003. "Enacting democracy.” Political Studies 51: 161- 179.

Saward, Michael. 2009. "Authorization and authenticity: representation and the unelected.” Journal of Political Philosophy 17: 1-22.

Scholte, Jan A. 2007. "Civil society and the legitimation of global governance." Journal of Civil Society 3: 305-326.

Sen, Amartya. 2008. “The idea of justice.” Journal of Human Development 9: 331-342.

Skinner, Quentin. 1973. "The empirical theorists of democracy and their critics: a plague on both their houses." Political Theory 1: 287-306.

Thompson, Grahame F. 2005. "Global corporate citizenship: what does it mean?” Competition and Change 9: 203-224.

Wendt, Alexander 2003. "Why a world state is inevitable." European Journal of International Relations 9: 4.

Young, Iris M. 2000. Inclusion and Democracy. Oxford: Oxford University Press.

Zolo, Danilo. 2000. "The lords of peace: from the Holy Alliance to the new international criminal tribunals." In Global Democracy: key debates, 73-86. Ed. Barry. Holden. London: Routledge. 


\section{NoTES}

1. Zolo's work (2000) is a clear exception, but one that tends to prove the rule.

2. As Quentin Skinner $(1973,287-306)$ argued in a timely intervention in the so-called elitist versus participationist debates in (largely American) democratic theory in the late 1960's and early 1970 's, 'democracy' is a term that, in present-day western and a number of other cultures, connotes something that just is commendable. This is not just a thing, but a good thing, and therefore something that there is an (implicit if not explicit) moral imperative to work towards.

3. Young $(2000,267)$ provides a notable example, in my view, with comments like ' ... I propose a global system of regulatory regimes to which locales and regions relate in a federated system', and 'In contrast to most international regulatory institutions, global governance should be organised democratically'.

4. This does not rule out prescription in political theory, as Gunnell himself notes, but it does raise the issue of the basis of prescriptions. I would favour an approach that is more partial and interpretive. Ideally one might draw out, and draw on, extant partial perspectives and practices. Amartya Sen notes one attractive manifestation of this sort of approach when he writes that 'it is useful to try to persuade the activists to tell us more about what drives them, because of the important support that their practical commitments get from their implicit philosophy' (Sen 2008, 333).

5. The following paragraphs draw upon my analysis in Saward (2003).

6. Here I draw loosely on Judith Butler's approach to 'gender'. Butler writes that '....the substantive effect of gender is performatively produced... gender is always a doing, though not a doing by a subject who might be said to pre-exist the deed... There is no gender identity behind the expressions of gender; that identity is performatively constituted by the very 'expressions' that are said to be its results' (Butler 1990: 24-5).

7. I claim no expertise on this issue. For relevant discussions see Manning (2002) and de Waal (2008).

8. Keane (2008) goes as far as to suggest that we have now entered a new phase of democracy, which he calls 'monitory democracy'. 